\title{
Viability of Titanium-Titanium Boride Composite as a Biomaterial
}

\author{
F. M. Makau, ${ }^{1}$ K. Morsi, ${ }^{1}$ N. Gude, ${ }^{2}$ R. Alvarez, ${ }^{2}$ M. Sussman, ${ }^{2}$ and K. May-Newman ${ }^{1}$ \\ ${ }^{1}$ Department of Mechanical Engineering, San Diego State University, 5500 Campanile Drive, San Diego, CA 92182, USA \\ ${ }^{2}$ Department of Biology, San Diego State University, 5500 Campanile Drive, San Diego, CA 92182, USA
}

Correspondence should be addressed to K. May-Newman; kmaynewm@mail.sdsu.edu

Received 16 April 2013; Accepted 4 June 2013

Academic Editors: W.-C. Chen, C. Galli, J. Toppari, and J. Wang

Copyright (C) 2013 F. M. Makau et al. This is an open access article distributed under the Creative Commons Attribution License, which permits unrestricted use, distribution, and reproduction in any medium, provided the original work is properly cited.

\begin{abstract}
The use of reinforcements to enhance mechanical properties of titanium such as hardness has been adopted by many researchers. Of these reinforcements, titanium boride has emerged as one of the most suitable reinforcements for titanium which is both chemically and mechanically compatible with the titanium matrix. Despite the extensive work conducted on these types of composites, very little is known about their biocompatibility which has so far precluded their use in bioapplications. The present paper investigates, for the first time, the biocompatibility of powder-processed titanium-titanium boride $\left(\mathrm{Ti}-\mathrm{TiB}_{\mathrm{w}}\right)$ composites for use in medical and dental implants and basic studies on fibroblast attachment conducted to assess $\mathrm{Ti}^{-\mathrm{TiB}_{\mathrm{w}}}$ for this application. The work is intended to serve as an initial step towards understanding the bioresponse of these composites by evaluating cytotoxicity, cellular attachment and morphology, and hemolytic potential. Results indicate that fibroblasts attach, proliferate, and achieve confluency when in contact with the $\mathrm{Ti}_{-} \mathrm{TiB}_{\mathrm{w}}$ composites, exhibiting normal morphology. Furthermore, the cells show a favorable growth rate when cultured with the composite for 48 hours. The $\mathrm{Ti}^{-} \mathrm{TiB}_{\mathrm{w}}$ composite demonstrated excellent blood biocompatibility, with a low hemolysis level $(0.12 \%)$ when compared with $\mathrm{CP} \mathrm{Ti}(0.17 \%)$ and $\mathrm{Ti}-6 \mathrm{Al}-4 \mathrm{~V}(0.36 \%)$. These findings suggest that Ti-TiB ${ }_{\mathrm{w}}$ composite is biocompatible and further investigation into its suitability as a biomaterial should be considered.
\end{abstract}

\section{Introduction}

Medical implants present a challenging set of mechanical and biocompatibility requirements. These devices must withstand large torques, compressive and shear forces during their normal loading conditions and require strong wear-resistant materials for good mechanical force transfer. Biological integration of the implant requires biocompatibility with both hard and soft tissues and prevention of bacterial adhesion, infection, and blood hemolysis [1]. Titanium (Ti) alloys such as Ti-6 Al- $4 \mathrm{~V}$ and commercially pure titanium $(\mathrm{CP} \mathrm{Ti}$ ) have been widely used in medical implants due to their excellent biocompatibility and mechanical properties [2]. However, problems such as wear particle generation and the associated inflammatory response present a need for further improvement for biomedical applications [3]. Titanium composites present a viable solution and provide many benefits in terms of property improvements compared with unreinforced Ti. However, the search for a suitable reinforcement material for the titanium matrix that is both mechanically and chemically compatible had been a major challenge for many years. Recently, titanium boride $\left(\mathrm{TiB}_{\mathrm{w}}\right)$ has emerged as a highly suitable reinforcement for titanium, since it is chemically stable with the titanium matrix (and hence no undesirable reaction products are formed at their interface during processing or service at elevated temperatures). It also has a similar density and thermal expansion coefficient to titanium. The former avoids sacrificing the lightweight advantage of titanium by reinforcing it, and the latter avoids the generation of undesirable internal stresses within the composite. $\mathrm{TiB}_{\mathrm{w}}$ are normally introduced into the titanium matrix via an in situ reaction between titanium di-boride $\left(\mathrm{TiB}_{2}\right)$ and titanium, where $\mathrm{TiB}_{2}$ is consumed thereby forming $\mathrm{TiB}$ in single crystal whisker form. $\mathrm{Ti}^{-} \mathrm{TiB}_{\mathrm{w}}$ composites have since been found to significantly enhance the mechanical properties of titanium; however, a drop in ductility/toughness has been reported above a critical $\mathrm{TiB}_{\mathrm{w}}$ volume fraction, where whisker interlocking throughout the microstructure becomes dominant 


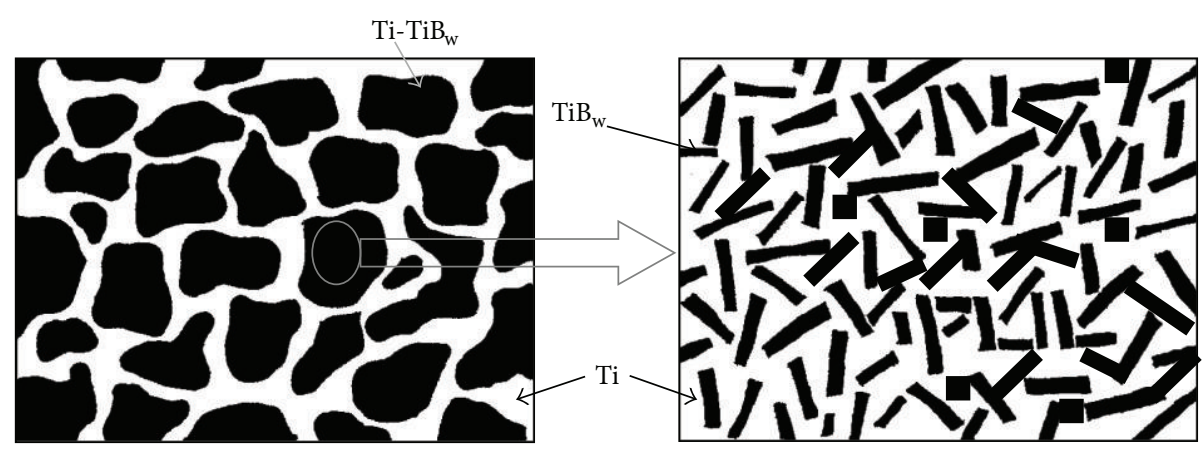

FIgURE 1: Schematic of dual matrix Ti-TiB ${ }_{\mathrm{w}}$ microstructural design [6].

[4]. To combat this problem we recently applied the dual matrix microstructural design to $\mathrm{Ti}^{-} \mathrm{TiB}_{\mathrm{w}}$ composites, where $\mathrm{TiB}_{\mathrm{w}}$ (of the same overall intended volume fraction) were selectively grown in localized regions of the microstructure while always leaving a ductile predominantly titanium region in between these localized regions (Figure 1 shows a schematic of the microstructure). This design has been also previously termed as "composite within a composite" [5]. This can easily be understood with reference to Figure 1 where the dark reinforced particles in the titanium matrix are themselves "composite" particles of $\mathrm{Ti}$ and $\mathrm{TiB}_{\mathrm{w}}$.

This microstructural design has been adopted to produce tungsten carbide- (WC-)cobalt (Co)/cobalt [5, 7], WCCo/Steel, aluminum 6061-Silicon carbide (composite fiber)/ aluminum 6061 [8], and recently spark plasma extruded pure aluminum-carbon nanotube/aluminum dual matrix composites [9]. Unique combinations of properties have reported, for example, an order of magnitude enhancement in toughness [8] and increased wear resistance [5] over conventional composites reinforced at the same overall volume fraction. The latter has been attributed to the protection of the outer soft matrix by highly reinforced protruding composite regions of the microstructure. If determined to be biocompatible, then $\mathrm{Ti}-\mathrm{TiB}_{\mathrm{w}}$ dual matrix composites have significant potential as a biomaterial. Previous studies have focused on surface features or coatings that influence soft tissue/ fibroblast attachment [10], including micromachined grooves [11], surface charge [12], growth factors [13], and TiN [14]. However, these coatings do not significantly enhance the bulk properties of the material and are not precluded by the development of new structural alloys for dental implants. As such, the objective of this study is to gain insight into the soft tissue biocompatibility of $\mathrm{Ti}^{-} \mathrm{TiB}_{\mathrm{w}}$, which should pave the way for future extensive investigations of this material for dental implants. To the best of the authors' knowledge, to date, no study on the biocompatibility of $\mathrm{Ti}^{-} \mathrm{TiB}_{\mathrm{w}}$ conventional or dual matrix composites has been conducted.

\section{Materials and Methods}

Mechanically alloyed and classified $\mathrm{TiB}_{2} / \mathrm{Ti}$ precursor powder (63-90 m) (Atlantic Equipment Engineers, NJ, USA) was rotator mixed with an equal volume of commercially pure (CP) titanium powder. The mixed powder was then spark
TABLE 1: Summary of biocompatibility tests performed.

\begin{tabular}{lccc}
\hline Test name & Direct contact & $\begin{array}{c}\text { Agar } \\
\text { diffusion }\end{array}$ & Hemolysis \\
\hline ASTM no. & F813-01 (2002) & $\begin{array}{c}\text { F895-84 } \\
(2001)\end{array}$ & $\begin{array}{c}756-00 \\
\text { Test sample(s) }\end{array}$ \\
Ti-TiB & Ti-TiB $_{\mathrm{w}}$ & $\begin{array}{c}\text { Ti-TiB Ti } \\
\text { CP Ti-6Al-4V }\end{array}$ \\
Test subject & L929 & L929 & Rabbit blood \\
fibroblasts & fibroblasts & Buna N, \\
Positive control & Nitrile/Buna N & Latex & Latex \\
Negative control & HDPE & HDPE & HDPE \\
Number of replicates & 2 & 2 & 3 \\
\hline
\end{tabular}

plasma sintered in a graphite die having an internal diameter $19 \mathrm{~mm}$, at a temperature of $1100^{\circ} \mathrm{C}-1200^{\circ} \mathrm{C}$, using electric current $1000-1500 \mathrm{~A}$ and a pressure of $106 \mathrm{MPa}$ to produce $\mathrm{Ti}^{-} \mathrm{TiB}_{\mathrm{w}}$ dual matrix composites. Experimental and processing details have been reported elsewhere [15]. A representative microstructure of the $\mathrm{Ti}^{-\mathrm{TiB}_{\mathrm{w}}}$ dual matrix composites is shown in Figure 2. Throughout the paper, the material will be referred to as $\mathrm{Ti}^{-}-\mathrm{TiB}_{\mathrm{w}}$.

The biocompatibility of the processed materials was assessed with cultured fibroblasts using standardized tests in accordance with ISO9000 ASTM standards [16-18] as noted in Table 1 . These tests are widely used by researchers and industry to screen the potential reaction of a sample of material with cells, tissue, and blood. Additional tests are needed to assess biocompatibility of the finished product in combination with other materials and in specific geometrical forms. Thus, these ASTM biocompatibility tests provide a preliminary but valuable assessment of the basic biocompatibility of the material.

Fibroblast attachment, growth, and morphology were assessed qualitatively using light microscopy. Cytotoxicity of $\mathrm{Ti}^{-} \mathrm{TiB}_{\mathrm{w}}$ was evaluated with two different tests: the Direct Contact (DC) following ASTM F813-01 and Agar Diffusion (AD) following ASTM F895-84 [16, 17]. Hemolysis tests (H) were performed using the procedure defined in ASTM 75600 [18]. For all tests, high density polyethylene, HDPE (PlastiCraft, West Nyack, NY, USA) was used as the negative control. 


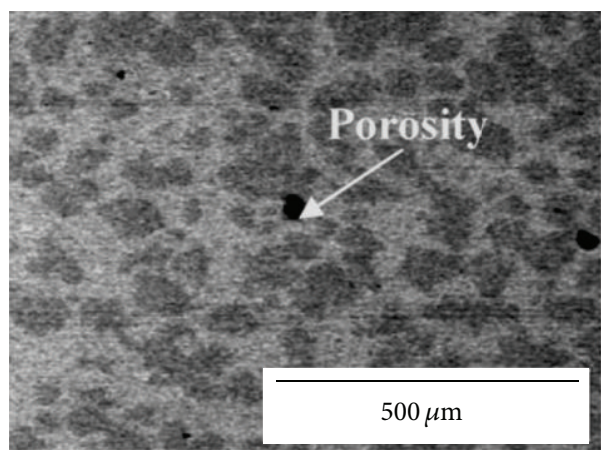

(a)

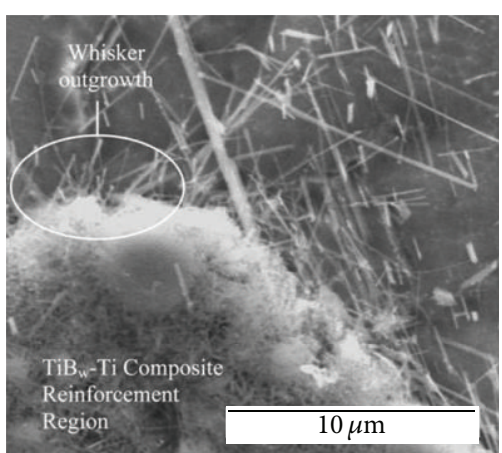

(b)

FIGURE 2: Scanning electron micrographs of spark plasma sintered $\mathrm{Ti}^{-} \mathrm{TiB}_{\mathrm{w}}$ dual matrix composite $[6,15]$.

Nitrile or Buna N (RubberCal, Santa Ana, CA, USA) and latex (Small Parts Inc., Miramar, FL, USA) were used as positive controls for the DC and AD tests, respectively. Buna N and latex were used as a "low" positive control and "intermediate" positive control in the $H$ test. For the $H$ test, additional test samples of $\mathrm{CP}$ titanium grade 2 (United Titanium Inc, $\mathrm{OH}$, USA, lot M392390) and Ti-6Al-4V grade 5 (United Titanium Inc, OH, USA, lot M435060) were prepared and tested for comparison. The controls and test samples were sterilized at $121^{\circ} \mathrm{C}$ for 25 minutes at $14 \mathrm{psi}$ under steam in an autoclave. The latex specimens were autoclaved for 10-15 minutes to prevent deterioration. Duplicate samples were prepared for the $\mathrm{DC}$ and $\mathrm{AD}$ cytotoxicity tests while triplicate samples were prepared for the $H$ testing.

2.1. Cell Culture. Mouse connective tissue fibroblasts L929 (ATCC cell line CCLl, NCTC clone 929, derivative of Strain L) (ATCC, Manassas, VA, USA) were plated and cultured following procedures provided by ATCC. Cells were passaged six times prior to performing the cell cultures for DC and $\mathrm{AD}$ cytotoxicity testing. The cells were incubated for 2-3 days until a near-confluent monolayer showed no signs of malformations, granulation, or sloughing.

2.2. DC Cytotoxicity Test. Duplicate test and control samples were placed in direct contact with the cell layer and incubated at $37^{\circ} \mathrm{C}$ with $5 \%$ carbon dioxide for $24 \pm 1$ hours. The 6well plates also contained two wells of cells but devoid of any specimens. After incubation and removal of the test and control specimens, the cell cultures were examined with a Leica DM1L inverted microscope (Leica Microsystems Wetzlar GmBH, Germany) equipped with a Motic Images Plus 2.O ML camera.

2.3. AD Cytotoxicity and Timeline Study. Two sets of tests each with duplicate positive control, negative controls, samples, and blank wells (with cells but no specimens) were performed. Cell culture images prior to incubation, $t=0$, were taken. The first set of samples was incubated for $24 \pm 1$ hours at $37^{\circ} \mathrm{C}$ with $5.0 \%$ carbon dioxide, while the second set was incubated for $48 \pm 1$ hours at $37^{\circ} \mathrm{C}$ with $5.0 \%$ carbon dioxide. After each incubation period, the culture dishes were removed and an outline of the specimens was marked on the bottom of the wells. The specimens were carefully removed and the cell cultures were examined and images were taken. This was followed by addition of $0.01 \%$ neutral red stain (Cat no. 415490250, Acros Organics, NJ, USA), incubating for one hour and then aspirating the neutral red. Viable cells are stained with neutral red while dead cells remain unstained. Any zone of lysis was marked and observations were recorded. To quantify the cytotoxic effect of the specimens on the cell cultures, the Zone and the Lysis Indices were determined. The Zone Index is a measure of the clear region in which there are unstained cells (dead cells) while the Lysis Index is a measure of the number (percent) of cells affected within the clear zone [17]. A Response Index, the relationship between the Zone and Lysis Index, was determined and reported as a fraction.

The timeline study assessed the AD cytotoxicity at 24 and 48 hours and evaluated cell growth for both test and control specimens. Cell growth underneath the specimens and outside the specimen areas was evaluated separately. Cell density (number $/ \mathrm{cm}^{2}$ ) was determined by counting the cells within a specific area using Image J (NIH, http://rsbweb.nih.gov/ $\mathrm{ij} /$ index.html), and cell culture growth ratios were calculated by normalizing the value by the cell density at time 0 .

2.4. $H$ Test. The $H$ test was conducted under static conditions [18]. The calibration curve was consistent with the International Committee of Standardization in Hematology (ICSH) procedure and was prepared using cyanmethemoglobin reagent (Stanbio, USA, TX, Cat no. 0320-650, lot 06781, ex 03/2010) reconstituted per supplier's instructions and cyanmethemoglobin standard (Stanbio, TX, USA, Cat no. 0325-015, lot 24971, $80 \mathrm{mg} / \mathrm{dL}$, exp 09-2009).

The hemolysis study was conducted following approval by the SDSU IACUC for tissue use and collection. Approximately $4.5 \mathrm{~mL}$ of arterial rabbit blood was drawn from three adult New Zealand type rabbits into $4.5 \mathrm{~mL}$ tubes containing $0.105 \mathrm{M}$ buffered sodium citrate. These tubes containing the anticoagulated blood were stored at $4 \pm 2^{\circ} \mathrm{C}$ and used within 24 hours. Three milliliter quantities from each vial were pooled together prior to use. Absorbance of diluted standards was measured using a Biospec-1601 UV-Visible spectrophotometer (Shimadzu, Japan) set at $540 \mathrm{~nm}$ and capable of taking 
measurements to four decimal places. Cyanmethemoglobin $(\mathrm{CMH})$ diluent was used as the zero blank. A calibration curve was generated using Excel software (Microsoft, WA, USA). Plasma free hemoglobin (PFH) and total blood hemoglobin concentration $(\mathrm{TBH})$ were determined [18]. Following the recommended sample weight per volume of extract vehicle of $1.4-3.5 \mathrm{~g}$ per $7 \mathrm{~mL}$ of phosphate buffered saline (PBS), preweighed positive controls (Buna $\mathrm{N}, n=3$, $1.66 \mathrm{~g}$ and Latex, $n=3,1.66 \mathrm{~g}$ ), negative control (HDPE, $n=3,1.66 \mathrm{~g}), \mathrm{Ti}_{-}-\mathrm{TiB}_{\mathrm{w}}(n=3,1.66 \mathrm{~g}), \mathrm{CP} \mathrm{Ti}(n=3,1.98)$, and Ti-6Al-4V ( $n=3,2.10 \mathrm{~g})$ samples were used. Buna $\mathrm{N}$ was considered as a low positive control and is hereby considered a "conservative" material for this test. A latex positive control sample, considered here as an "intermediate" control, was also used for comparison with Buna N. Cell morphology after exposure to these two positive controls aids in calibrating of $\%$ hemolysis values and validating the spectroscopic data. Two sets of tubes with PBS were added to the test to serve as test control (blank) and quality control (QC) tubes $(1 \mathrm{~mL}$ of the undiluted $\mathrm{CMH}$ standard $(0.8 \mathrm{mg} / \mathrm{mL})$ in $7 \mathrm{~mL}$ of PBS). The tubes were placed in a $37 \pm 2^{\circ} \mathrm{C}$ water bath for 3 hours. During this time period, each tube was gently inverted every 30 minutes so as to ensure direct blood contact with the specimens. After incubation, the extract vehicle was decanted and then centrifuged in a Sorvall RT7 Plus centrifuge (GMI, Inc., Ramsey, MN, USA) set at 700-800 g for 15 minutes. The supernatant was carefully removed to avoid disturbing any erythrocytes at the pellet. Any anomalies such as color change of both the supernatant and the pellet were recorded. Supernatant hemoglobin concentration (SHC), hemoglobin concentration, the hemolysis percentage, or hemolytic index were determined. The hemolysis percentage was corrected for both the blank and negative control as follows [18]:

Blank corrected \% Hemolysis

$$
=\left[\frac{\left(A^{S}-A^{B}\right)}{\left(0.844 A^{T}\right)-\left(A^{B}\right)}\right] * 100,
$$

where $A^{S}, A^{B}$, and $A^{T}$ are the absorbance of the test sample supernatant, blank, and total hemoglobin, respectively. Similarly, the negative corrected \% hemolysis was calculated using the absorbance of the negative control. Studies were performed to ascertain the reproducibility of this test and the test results and percent coefficient of variation $(\% \mathrm{CV})$ assessed to measure the degrees of variability.

Several additions to the test protocol were made. First, the diluted blood and the extract fluid were observed microscopically at each stage to ascertain the status of the erythrocytes. Second, the test and control sample surfaces were observed prior to and after extraction. The interaction of the specimen surface and red blood cells was also investigated. This test was performed by carefully removing the specimens after extraction, allowing any excess fluid to run off and then observing the specimens under a Micromaster microscope (Fisher Scientific, USA). Any adhered cells, their location, morphology, or absence were noted.

\section{Results and Discussion}

3.1. Fibroblast Attachment and Morphology. Figure 3 shows mouse fibroblasts cultured for 24 hours on 4 different surfaces: three controls (negative, medium, and positive) and $\mathrm{Ti}-\mathrm{TiB}_{\mathrm{w}}$ composite. Cells grown on the $\mathrm{Ti}^{-} \mathrm{TiB}_{\mathrm{w}}$, as well as the medium and negative control surfaces, displayed good adhesion and spread well. Fibroblasts on the positive control surface were rounded, with few cells showing normal morphology. No preferred orientation was observed on any of the surfaces.

3.2. DC Test. For the DC test, cells in blank wells (without any control or test samples), in negative control wells, and in $\mathrm{Ti}-\mathrm{TiB}_{\mathrm{w}}$ wells appeared normal after $24 \pm 1$-hour incubation. The cells showed a confluent monolayer and had normal morphology. No cells' shrinkage, rupture, or change in cell density was observed. Cells had normal intracellular granules. Cells in positive control wells appeared abnormal and did not show a confluent monolayer, and a large percentage of the cells had a circular shape. There were a large variation of cell size and also severe destruction of the cell monolayer, and there was evidence of cell lysis and a decrease in cell density. All duplicate samples indicated similar results and the controls performed as expected. Figure 3 shows fibroblasts that were in contact with medium (blank), negative, positive, and $\mathrm{Ti}^{-} \mathrm{TiB}_{\mathrm{w}}$ samples.

3.3. AD and Timeline Study. For the AD cytotoxicity test, the cell cultures with the medium control, underneath or outside of the negative control, and $\mathrm{Ti}-\mathrm{TiB}_{\mathrm{w}}$ areas after either 24- and 48-hour incubation formed a confluent monolayer and did not indicate any malformations, lysis, or cell death. The cells were stained with the neutral red stain indicating that there was no cell death. A Response Index of $0 / 0$ was therefore assigned for each of these samples at both incubation times. There was also a decrease in cell layer density underneath the negative control and $\mathrm{Ti}^{-} \mathrm{TiB}_{\mathrm{w}}$ specimens. The cells underneath the positive control specimen after both 24 and 48-hour incubation were not stained indicating they were dead. There was a clear zone with a diameter of $1.9-2.1 \mathrm{~cm} \mathrm{(24}$ hours) and $2.0-2.1 \mathrm{~cm}$ (48 hours). The clear zones extended $0.5-0.6 \mathrm{~cm}$ away from the positive control specimen. The cells in this clear zone were not stained and nearly all of the cells in this zone were affected. Furthermore, the cell density in this zone had decreased. A Response Index of 3/5 was therefore assigned. $\mathrm{A} \mathrm{Ti}-\mathrm{TiB}_{\mathrm{w}}$ Response Index of $0 / 0$ equals that of the negative control and the medium control. Excellent biocompatibility responses have been demonstrated for titanium alloys in the past and are expected with this assay $[19,20]$.

For the timeline study, the average cell density within a specified area $\left(\right.$ cell $\left./ \mu \mathrm{m}^{2}\right)$ was measured, and cell culture growth ratios were calculated. Figure 4 shows the growth ratios for the controls, the $\mathrm{Ti}^{-} \mathrm{TiB}_{\mathrm{w}}$, and the blank wells. Cell cultures without any specimens (blank wells) had growth ratios of 2.3 and 2.6 at 24 - and 48 -hour intervals, respectively. Growth ratios for other cell cultures surrounded by specimens were lower. The $\mathrm{Ti}-\mathrm{TiB}_{\mathrm{w}}$ fibroblasts growth ratio underneath the specimen was 1.4 after $24 \mathrm{hr}$ and 1.8 after $48 \mathrm{hr}$ 


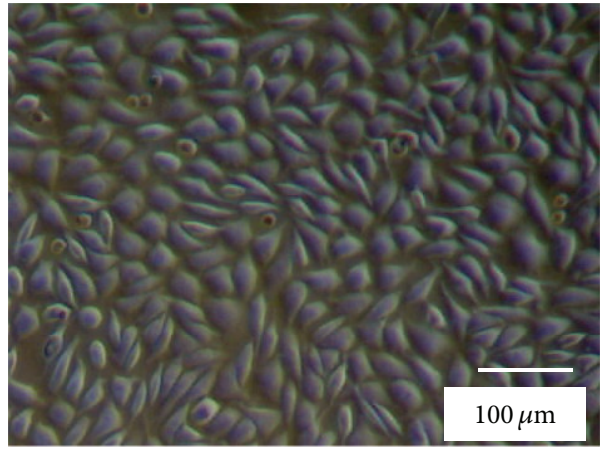

Medium control

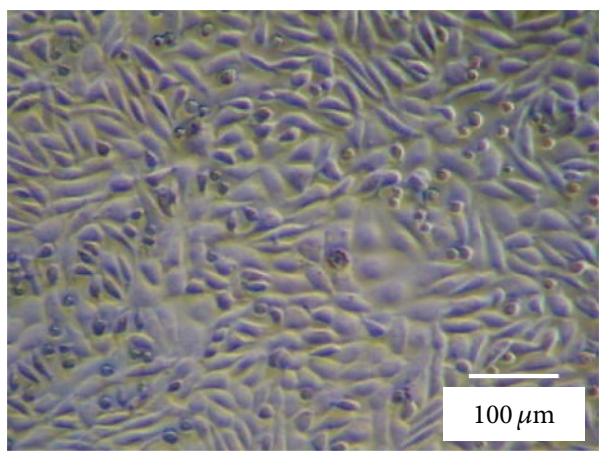

Negative control

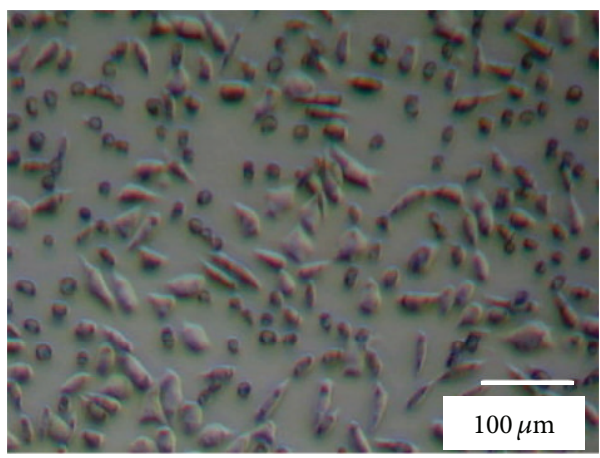

Positive control cells

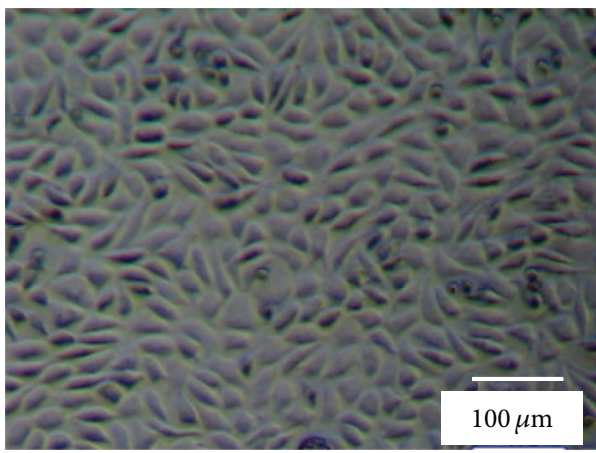

$\mathrm{Ti}^{-} \mathrm{TiB}_{\mathrm{w}}$ test sample

(a)

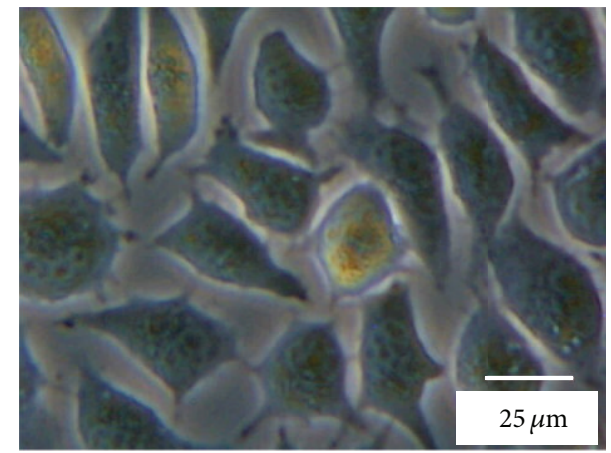

Medium control

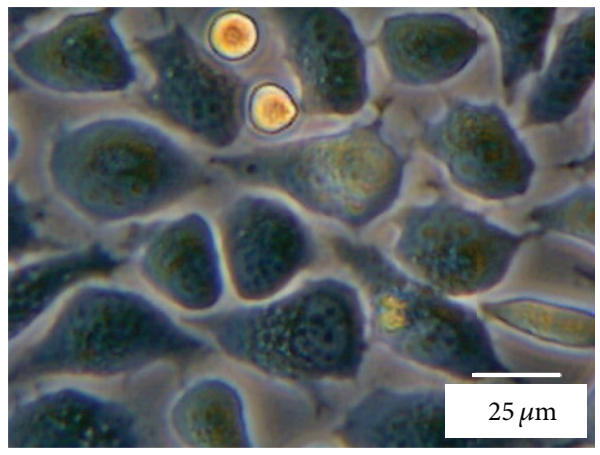

Negative control

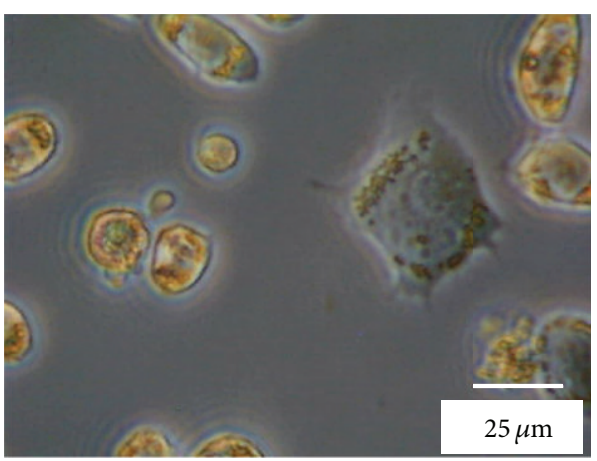

Positive control cells

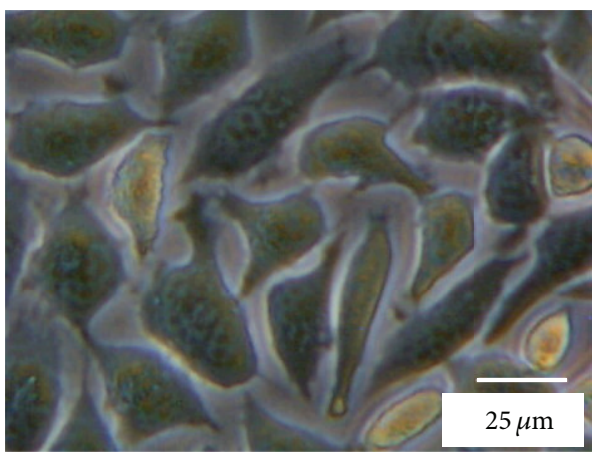

$\mathrm{Ti}^{-} \mathrm{TiB}_{\mathrm{w}}$ test sample

(b)

FiguRE 3: Images of fibroblasts from DC test after incubation at $37^{\circ} \mathrm{C}$ at low (a) and high (b) magnification for the three control materials (negative, medium, and positive) and the $\mathrm{Ti}^{-} \mathrm{TiB}_{\mathrm{w}}$ dual matrix composite. 


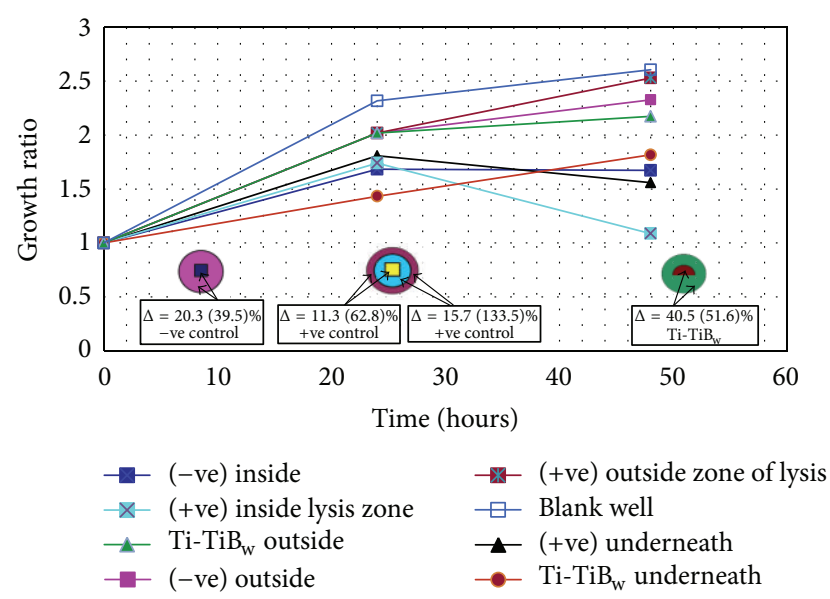

FIgURE 4: Growth ratios after 24 and 48 hours from $\mathrm{AD}$ time series study. The circular diagrams depict the sample regions analyzed for each well plate. +ve: positive control; -ve: negative control.

and was greater outside the specimen area. The timeline study also demonstrated that $\mathrm{Ti}^{-} \mathrm{TiB}_{\mathrm{w}}$ was not cytotoxic since lack of cell proliferation can be used as a measure of cytotoxicity [21]. In a study by Okazaki et al., a growth ratio of 1.0 was reported for Ti alloys, Ti-Zr and Ti-Sn [22]. The growth ratios of cells exposed to these alloys were slightly higher than those of Ti grade 2 and Ti-6Al-4V alloys also investigated in that study. The lower growth ratio for cell cultures underneath the $\mathrm{Ti}^{-} \mathrm{TiB}_{\mathrm{w}}$ sample specimens could be due to the fact that the $\mathrm{Ti}^{-} \mathrm{TiB}_{\mathrm{w}}$ specimen weighed more $(1.66 \mathrm{~g})$ than the other specimens $(0.22-0.44 \mathrm{~g})$ and could have had an effect as material weight is known to influence cell growth [21].

3.4. $H$ Test. For the $H$ test, two standards curves were generated to assess reproducibility. $R$-squared values of 1.0 were achieved in both cases, and a percent coefficient of variation (\%CV) of less than $20 \%$ was found. PFH of $0.43 \mathrm{mg} / \mathrm{mL}$ for the pooled rabbit blood was measured, which is within the recommended range of $<2 \mathrm{mg} / \mathrm{mL}$ [18]. The whole blood $\mathrm{TBH}$ was $13.07 \mathrm{~g} / \mathrm{dL}$ which is within the normal rabbit hemoglobin range of 10.0-15.5 g/dL [23]. The QC standard concentration measured was $0.72 \mathrm{mg} / \mathrm{mL}$ of hemoglobin which was within $10 \%$ of the standard hemoglobin concentration $(0.8 \mathrm{mg} / \mathrm{mL})$ used for testing. Figure 5 shows the hemolysis index results after correcting for the blank and negative control baselines.

The three test specimens $\left(\mathrm{Ti}^{-} \mathrm{TiB}_{\mathrm{w}}, \mathrm{CP} \mathrm{Ti}\right.$, and $\mathrm{Ti}-6 \mathrm{Al}-$ $4 \mathrm{~V}$ ) had hemolysis levels less than $1 \%$ after correction using the control. No morphological changes or significant erythrocyte reduction was observed on the extraction vehicle from the negative control, $\mathrm{Ti}^{-\mathrm{TiB}} \mathrm{w}, \mathrm{CP} \mathrm{Ti}$, or $\mathrm{Ti}-6 \mathrm{Al}-4 \mathrm{~V}$ before or after incubation. The Buna $\mathrm{N}$ positive control showed some slight RBC lysis, and the latex positive control showed significant RBC lysis. The erythrocytes in the latex extraction vehicle were not circular, had a slight variation in cell size, and also appeared to form clusters after incubation. This indicated that the latex (positive control) had an effect on the red blood cells. The effect was more severe than that seen with the Buna

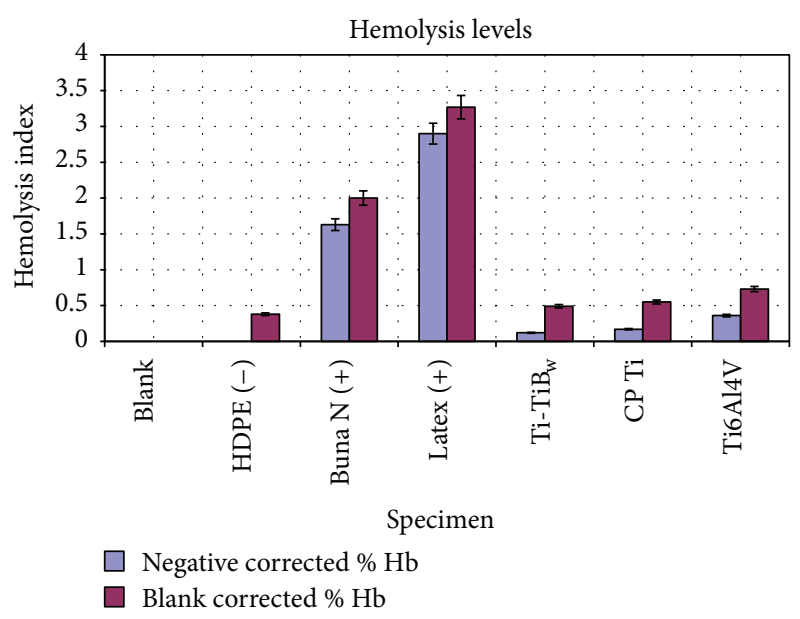

Figure 5: Hemolytic index for all specimens tested including negative and positive controls, $\mathrm{Ti}-\mathrm{TiB}_{\mathrm{w}}$, as well as $\mathrm{CP}$ (commercially pure) Ti and Ti-6Al-4V samples (Mean \pm Std. dev.). Hemolytic index is normalized to the negative sample and to the blank control.

$\mathrm{N}$ positive control. No erythrocytes were observed on any of the negative control and test material surfaces.

For the $H$ test, the positive and the negative controls performed as expected with all tests showing a \% CV of less than 20. The $\mathrm{Ti}^{-} \mathrm{TiB}_{\mathrm{w}}, \mathrm{CP} \mathrm{Ti}$, and Ti-6Al-4V alloys indicated a hemolytic index below $1 \%$ and showed no morphological changes to the erythrocytes. This indicated that these test samples were nonhemolytic and tolerated by the RBCs. For the CP Ti and Ti-6Al-4V, this is expected as these two materials have been found previously to be biocompatible $[24,25]$. However, the results of this study represent for the first time that $\mathrm{Ti}^{-} \mathrm{TiB}_{\mathrm{w}}$ has been demonstrated to be nonhemolytic. The hemolytic index above the negative control for the Ti- $6 \mathrm{Al}-4 \mathrm{~V}$ alloy $(0.36 \%)$ is double that of $\mathrm{CP} \mathrm{Ti}(0.17)$ and three times that of $\mathrm{Ti}^{-\mathrm{TiB}_{\mathrm{w}}}(0.12 \%)$. The higher hemolytic index of Ti$6 \mathrm{Al}-4 \mathrm{~V}$ could be due to the presence of vanadium, which can be harmful if unalloyed $[22,26]$. The boron component in the $\mathrm{TiB}_{\mathrm{w}}$ whiskers, at the exact volume fraction (28.5-29\% TiB) or below used in this study does not appear to have any adverse effect on the erythrocytes.

\section{Limitations}

The results from the AD test indicated that there was reduced cell culture growth underneath the positive and negative controls and $\mathrm{Ti}^{-} \mathrm{TiB}_{\mathrm{w}}$. This could be a result of removing the specimens which might have had adhered cells. Wang and Li evaluated the biocompatibility of $\mathrm{CP} \mathrm{Ti}$ and $\mathrm{Ni}-\mathrm{Cr}$ by using L929 fibroblast cells and the AD method and observed that fibroblasts attached to the test materials. They attributed this to the biocompatible nature of the alloys [27]. The standardized tests conducted in this study allow direct comparison of $\mathrm{Ti}^{-} \mathrm{TiB}_{\mathrm{w}}$ with other materials, but the results are insufficient to predict long-term biocompatibility in a medical or dental application without additional testing. This preliminary study however is a first important step towards demonstrating $\mathrm{Ti}^{-\mathrm{TiB}_{\mathrm{w}}}$ biocompatibility. 


\section{Conclusions}

The following conclusions can be drawn.

(1) $\mathrm{Ti}-\mathrm{TiB}_{\mathrm{w}}$, synthesized using the spark plasma sintering process, is not cytotoxic. $\mathrm{Ti}^{-\mathrm{TiB}_{\mathrm{w}}}$ composites do not produce abnormal morphology in fibroblast cells. Cells in wells containing $\mathrm{Ti}^{-} \mathrm{TiB}_{\mathrm{w}}$ show a favorable growth rate for 48 hours indicating that $\mathrm{Ti}-\mathrm{TiB}_{\mathrm{w}}$ is biocompatible at the basic cellular level.

(2) $\mathrm{Ti}-\mathrm{TiB}_{\mathrm{w}}$ does not cause red blood cell destruction or abnormal adhesion and thus is not hemolytic. It has a hemolysis level comparable to $\mathrm{CP} \mathrm{Ti}$ and is slightly better than Ti-6Al-4V, two established biocompatible materials that are used extensively in commercially available medical implants.

(3) While $\mathrm{Ti}-\mathrm{TiB}_{\mathrm{w}}$ contains boron-based whiskers, it does not exhibit any toxicity related to boron. Due to possible dissolution or leaching of the boron component and whisker debris, additional long-term biocompatibility studies are needed.

(4) The results presented in this study show the viability of $\mathrm{Ti}-\mathrm{TiB}_{\mathrm{w}}$ dual matrix composite as a biomaterial.

The $\mathrm{Ti}-\mathrm{TiB}_{\mathrm{w}}$ material is designed to reduce the problems of current titanium alloys. This material system and microstructural design present opportunities for the microstructural/property tailorability of biomedical implants, if proven to be biocompatible.

\section{List of Symbols}

$A^{S}$ : $\quad$ Absorbance of test sample supernatant

$A^{B}$ : $\quad$ Absorbance of blank sample

$A^{T}$ : $\quad$ Absorbance of total hemoglobin

AD: Agar diffusion

ASTM: American Society for Testing and Materials

CMH: Cyanmethemoglobin

CP: Commercially pure

CV: Coefficient of variation

DC: Direct contact

Hemo: Hemolysis

HDPE: High density polyethylene

PFH: Plasma-free hemoglobin

QC: Quality control

RBC: Red blood cell

SHC: Supernatant hemoglobin concentration

TBH: Total blood hemoglobin

Ti: $\quad$ Titanium

TiB: $\quad$ Titanium boride

$\mathrm{TiB}_{\mathrm{w}}$ : Titanium boride whiskers

Ti-TiB ${ }_{\mathrm{w}}$ : Titanium-titanium boride composites

$\mathrm{TiB}_{2}$ : Titanium di-boride.

\section{Conflict of Interests}

The authors of this paper do not have any direct financial relation with the commercial identity mentioned in the paper that might lead to a conflict of interests or not.

\section{Acknowledgments}

$\mathrm{Ti}^{-} \mathrm{TiB}_{\mathrm{w}}$ powder consolidation work was conducted using a spark plasma sintering system at the University of California, Riverside, in collaboration with Professor J. Garay. The authors also wish to thank Mr. Vipul Patel for powder processing of $\mathrm{Ti}^{-} \mathrm{TiB}_{\mathrm{w}}$. They would also like to thank Ms. Morag Mackay at San Diego Mesa College for supplying the rabbit blood samples and the San Diego AALAS chapter for their assistance.

\section{References}

[1] F.-Y. Teng, C.-L. Ko, H.-N. Kuo et al., "A comparison of epithelial cells, fibroblasts, and osteoblasts in dental implant titanium topographies," Bioinorganic Chemistry and Applications, vol. 2012, Article ID 687291, 9 pages, 2012.

[2] M. Geetha, A. K. Singh, R. Asokamani, and A. K. Gogia, “Ti based biomaterials, the ultimate choice for orthopaedic implants-a review," Progress in Materials Science, vol. 54, no. 3, pp. 397-425, 2009.

[3] B. Ratner, Orthopedic Materals and Applications, Biomaterials Science, 2002.

[4] K. Morsi and V. V. Patel, "Processing and properties of titaniumtitanium boride (TiBw) matrix composites-a review," Journal of Materials Science, vol. 42, no. 6, pp. 2037-2047, 2007.

[5] X. Deng, B. R. Patterson, K. K. Chawla et al., "Microstructure/hardness relationship in a dual composite," Journal of Materials Science Letters, vol. 21, no. 9, pp. 707-709, 2002.

[6] V. V. Patel, A. El-Desouky, J. E. Garay, and K. Morsi, "Pressureless and current-activated pressure-assisted sintering of titanium dual matrix composites: effect of reinforcement particle size," Materials Science and Engineering A, vol. 507, no. 1-2, pp. 161-166, 2009.

[7] X. Deng, B. R. Patterson, K. K. Chawla et al., "Mechanical properties of a hybrid cemented carbide composite," International Journal of Refractory Metals and Hard Materials, vol. 19, no. 4-6, pp. 547-552, 2001.

[8] V. C. Nardone, J. R. Strife, and K. M. Prewo, "Microstructurally toughened particulate-reinforced aluminum matrix composites," Metallurgical Transactions. A, vol. 22, no. 1, pp. 171-182, 1991.

[9] K. Morsi, A. M. K. Esawi, P. Borah, S. Lanka, A. Sayed, and M. Taher, "Properties of single and dual matrix aluminum-carbon nanotube composites processed via spark plasma extrusion (SPE)," Materials Science and Engineering A, vol. 527, no. 21-22, pp. 5686-5690, 2010.

[10] A. Furuhashi, Y. Ayukawa, I. Atsuta, H. Okawachi, and K. Koyano, "The difference of fibroblast behavior on titanium substrata with different surface characteristics," Odontology, vol. 100, no. 2, pp. 199-205, 2012.

[11] J. Guillem-Marti, L. Delgado, M. Godoy-Gallardo, M. Pegueroles, M. Herrero, and F. J. Gil, "Fibroblast adhesion and activation onto micro-machined titanium surfaces," Clinical Oral Implants Research, vol. 24, no. 7, pp. 770-780, 2013.

[12] M. Hamdan, L. Blanco, A. Khraisat, and I. F. Tresguerres, "Influence of titanium surface charge on fibroblast adhesion," Clinical Implant Dentistry and Related Research, vol. 8, no. 1, pp. 32-38, 2006.

[13] C. Bates, V. Marino, N. L. Fazzalari, and M. Bartold, "Soft tissue attachment to titanium implants coated with growth factors," 
Clinical Implant Dentistry and Related Research, vol. 15, no. 1, pp. 53-63, 2013.

[14] B. Groessner-Schreiber, A. Neubert, W.-D. Müller, M. Hopp, M. Griepentrog, and K.-P. Lange, "Fibroblast growth on surfacemodified dental implants: an in vitro study," Journal of Biomedical Materials Research Part A, vol. 64, no. 4, pp. 591-599, 2003.

[15] K. Morsi, V. V. Patel, K. S. Moon, and J. E. Garay, "Currentactivated pressure-assisted sintering (CAPAS) and nanoindentation mapping of dual matrix composites," Journal of Materials Science, vol. 43, no. 12, pp. 4050-4056, 2008.

[16] American Society of Testing and Materials, "Direct contact cell culture evaluation of materials for medical devices," ASTM F813-01, ASTM International, Conshohocken, Pa, USA, 2002.

[17] American Society of Testing and Materials, "Agar diffusion cell culture screening for cytotoxicity," ASTM Standard F895-84, ASTM International, Conshohocken, Pa, USA, 2002.

[18] American Society of Testing and Materials, "Standard practice for assessment of hemolytic properties of materials," ASTM 75600, ASTM International, Conshohocken, Pa, USA, 2000.

[19] M. Assad, A. Chernyshov, M. A. Leroux, and C.-H. Rivard, "A new porous titanium-nickel alloy: part 1. Cytotoxicity and genotoxicity evaluation," Bio-Medical Materials and Engineering, vol. 12, no. 3, pp. 225-237, 2002.

[20] D. J. Wever, A. G. Veldhuizen, M. M. Sanders, J. M. Schakenraad, and J. R. Van Horn, "Cytotoxic, allergic and genotoxic activity of a nickel-titanium alloy," Biomaterials, vol. 18, no. 16, pp. 1115-1120, 1997.

[21] M. Morita, T. Hashimoto, K. Yamauchi, Y. Suto, T. Homma, and Y. Kimura, "Evaluation of biocompatibility for titanium-nickel shape memory alloy in vivo and in vitro environments," Materials Transactions, vol. 48, no. 3, pp. 352-360, 2007.

[22] Y. Okazaki, S. Rao, Y. Ito, and T. Tateishi, "Corrosion resistance, mechanical properties: corrosion fatigue strength and cytocompatibility of new Ti alloys without A1 and V," Biomaterials, vol. 19, no. 13, pp. 1197-1215, 1998.

[23] J. E. Harkness and J. E. Wagner, The Biology and Medicine of Rabbits and Rodents, Williams and Wilkins, Baltimore, Md, USA, 4th edition, 1995.

[24] V. Biehl, T. Wack, S. Winter, U. T. Seyfert, and J. Breme, "Evaluation of the haemocompatibility of titanium based biomaterials," Biomolecular Engineering, vol. 19, no. 2-6, pp. 97-101, 2002.

[25] I. Dion, C. Baquey, J.-R. Monties, and P. Havlik, "Haemocompatibility of Ti6Al4V alloy," Biomaterials, vol. 14, no. 2, pp. 122126, 1993.

[26] M. F. López, A. Gutiérrez, and J. A. Jiménez, “In vitro corrosion behaviour of titanium alloys without vanadium," Electrochimica Acta, vol. 47, no. 9, pp. 1359-1364, 2002.

[27] R. R. Wang and Y. Li, "In vitro evaluation of biocompatibility of experimental titanium alloys for dental restorations," The Journal of Prosthetic Dentistry, vol. 80, no. 4, pp. 495-500, 1998. 

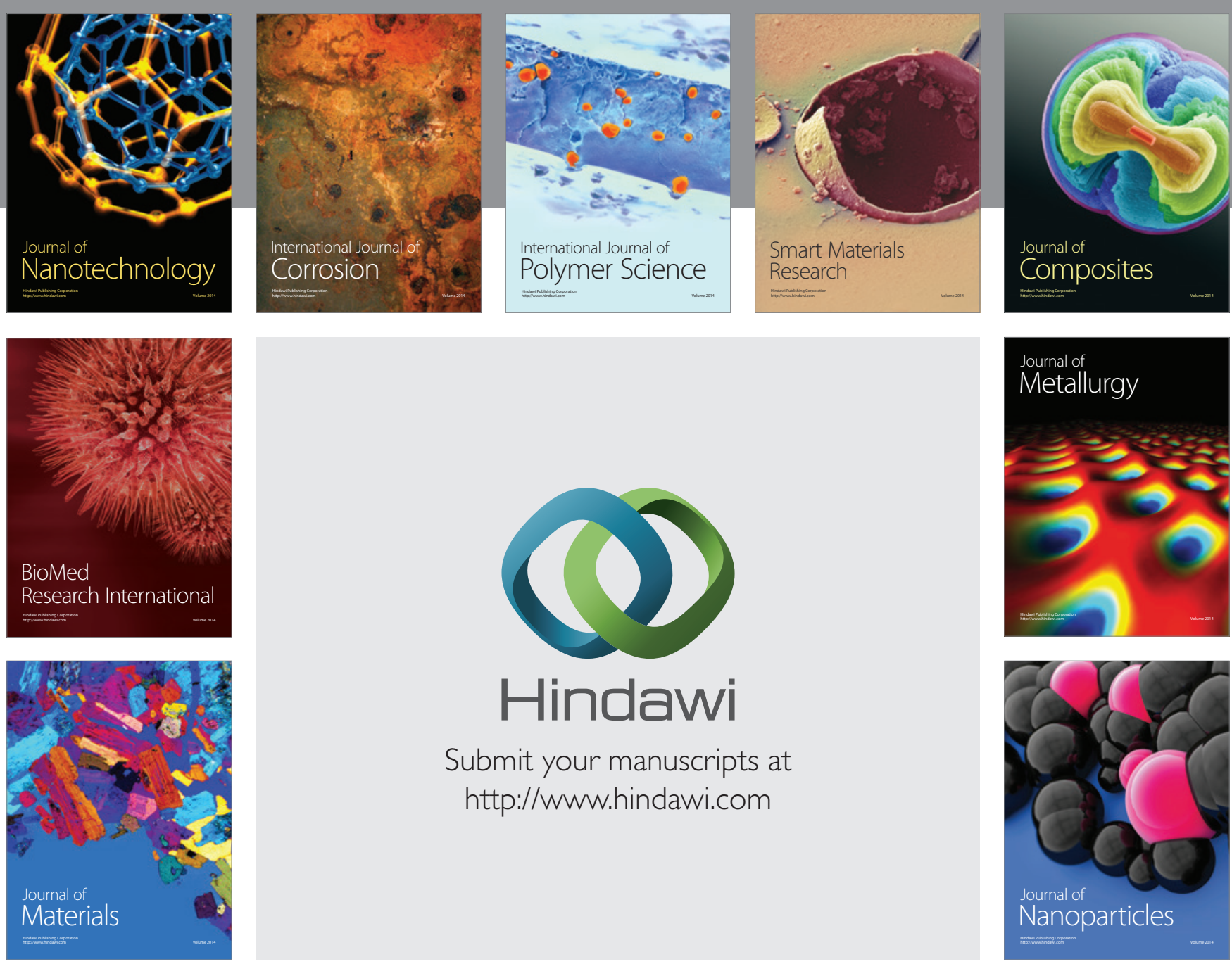

Submit your manuscripts at http://www.hindawi.com
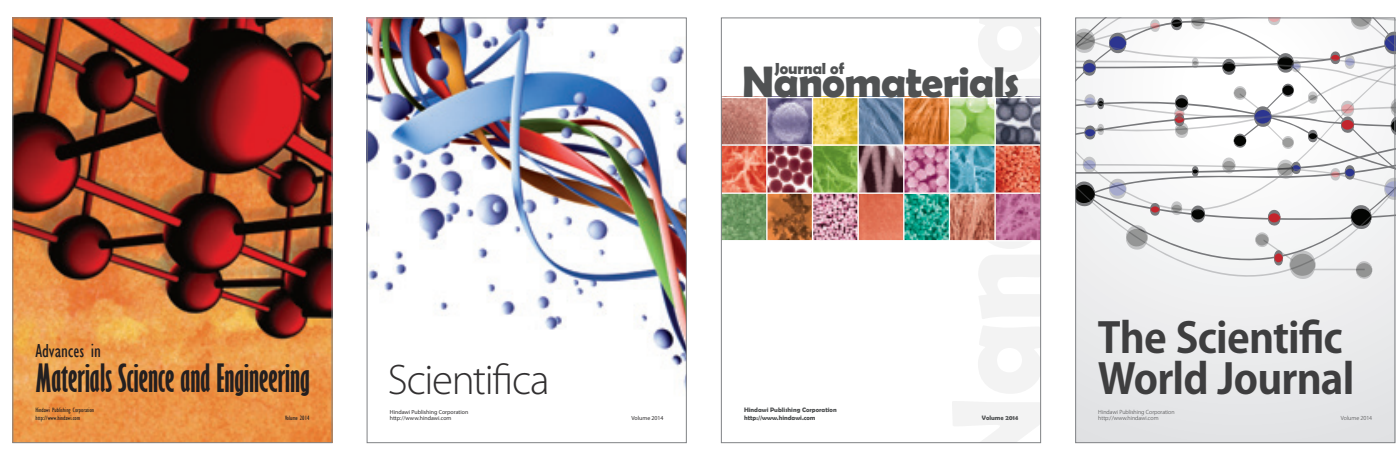

\section{The Scientific World Journal}
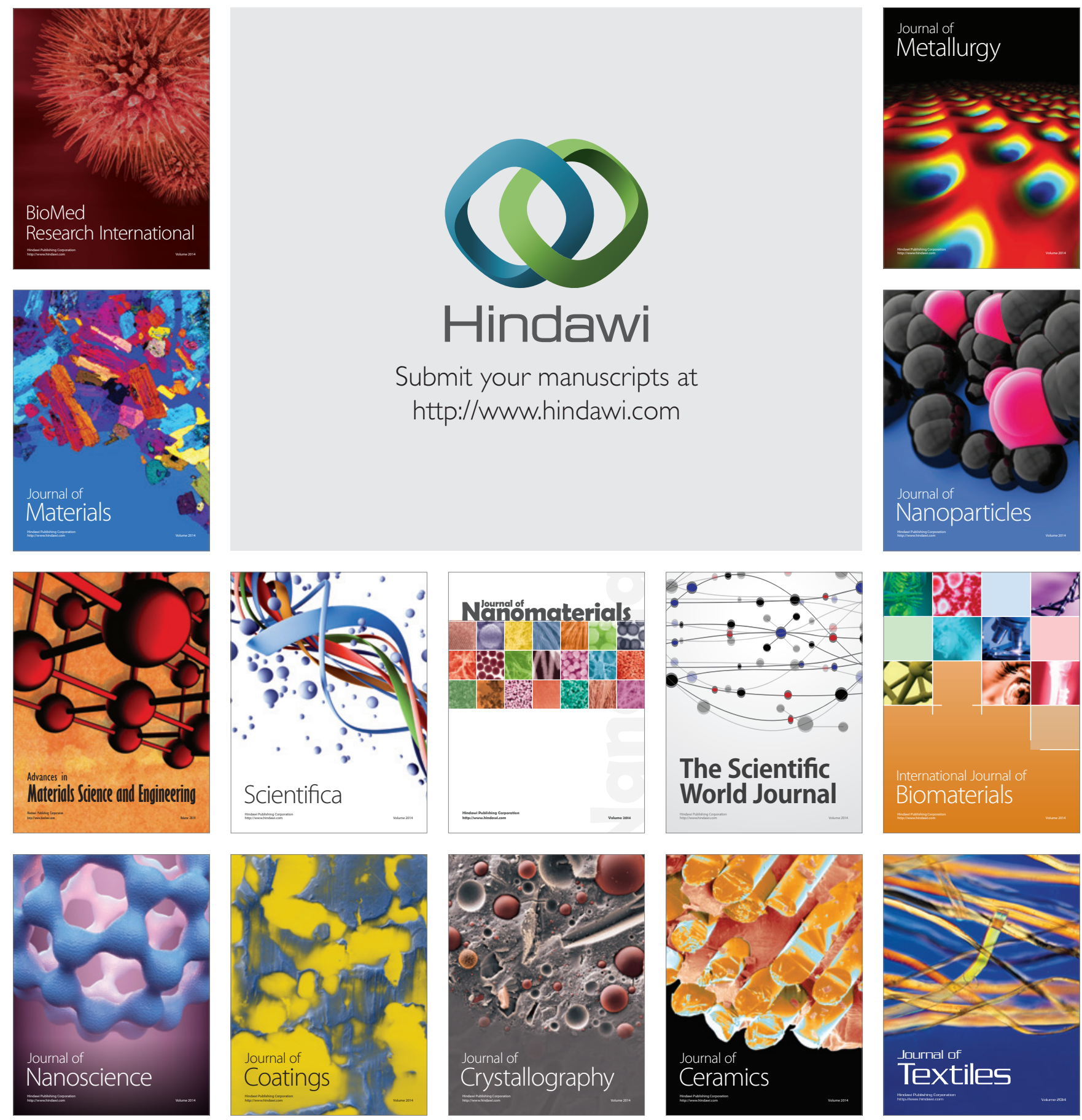